\title{
DETERMINATION OF FERMENTATIVE YEAST ACTIVITY BY CARBON DIOXIDE BY MANOMETRY METHOD
}

\author{
V. Ridkous \\ National University of Food Technologies
}

\begin{tabular}{l} 
Key words: \\
Fermentative yeast \\
activity \\
Carbon dioxide \\
Manometry \\
\hline
\end{tabular}

Article history:

Received 08.11.2018

Received in revised form

29.11.2018

Accepted 11.12.2018

Corresponding author:

V. Ridkous

E-mail:

Ridkous@ukr.net

\begin{abstract}
Efficiency and simplicity of measurements is an important task in determining the fermentative yeast activity by carbon dioxide by manometry method. Fermentative yeast activity is a capacity of yeast mass to ferment certain mass of sugar to ethanol and carbon dioxide in time unit and in certain temperature and $\mathrm{pH}$. Determination of fermentative yeast activity by volume of lost carbon dioxide is widely used. It is implemented by means of laboratory equipment of different constructions - zymotachygraph. But all of them have a demerit - measuring is occurred on stage of yeast adapting to the fermentation ambient (lag phase), and results of fermentation dynamics are more comparative than real. In order to measure the fermentative yeast activity in conditions that are closer to production (with taking into account of extreme pressure) volume of lost carbon dioxide has been determined by means of manometry (in escalation of pressure from 0 till 1.0 bar) and by analytical calculations. To avoid different unconsidered factors measurements of lost carbon dioxide by pressure have been taken in parallel - in experiment and in reference samples. The paper presents trial of determining the lost carbon dioxide of fermented wort by means of manometry. The fermentation of model wort - saccharose solution — has been done by selected yeast. Determination of lost carbon dioxide amount on different steps of fermentation has been done by dynamics of pressure growth. It was converted into volume by analytical equations. Counted volume of lost carbon dioxide in system was compared to the volume that was measured in exhausting in atmosphere (from given level of pressure till 0 ) by means of standard method ("wet gasholder"). To divide meaning of pressure/volume of carbon dioxide to time the speed of pressure/volume accumulating for time unit - fermentative yeast activity - has been found. The possibility of using the manometry and analytical calculations for express method for determining the lost carbon dioxide in fermented wort has been proved. Results of manometry measuring in frame of experimental accuracy are correlated with results made by standard method ("wet gasholder"). Average deviations in finding the lost carbon dioxide by manometry method are mostly depend on accuracy of pressure measurement $-1.5 \mathrm{vol} . \%$ in this case.
\end{abstract}

DOI: $10.24263 / 2225-2924-2018-24-6-26$ 


\title{
ВИЗНАЧЕННЯ БРОДИЛЬНОӤ АКТИВНОСТІ ДРІЖДЖІВ ЗА ВУГЛЕКИСЛИМ ГАЗОМ МАНОМЕТРИЧНИМ МЕТОДОМ
}

\author{
В.В. Рідкоус \\ Наиіональний університет харчових технологій
}

Актуальним завданням при визначенні бродильної активності дріжджів за вуглекислим газом манометричним методом є оперативність і простота замірів. Бродильна активність дріжджів - ие спроможність одиниці маси дріжджів за одинищю часу при заданій температурі і рН зброджсвати певну масу иукрів до етилового спирту і вуглекислого газу. Широко розповсюджене визначення бродильної активності дріжджів за об 'ємом виділеного вуглекислого газу здійснюється на різноманітних конструкиіях лабораторних установок - зимографів. Але всі вони мають головний недолік - визначення відбувається на стадії пристосування дріжджів (лаг-фаза) до середовища бродіння, а результати мають більше порівняльний характер, ніж відображають реальну картину динаміки бродіння. Для визначення бродильноі активності дріжджів, в умовах близьких до виробничих (з урахуванням дї надлишкового тиску), об'єм виділеного вуглекислого газу знаходили манометричним методом (при наростанні тиску від 0 до 1,0 бар) та аналітичними розрахунками. Для усунення різноманітних факторів, які неможливо врахувати, заміри виділеного вуглекислого газу за тиском проводили паралельно - в досліді і контролі.

У статті зроблена спроба визначення виділеного вуглекислого газу зброджуваного сусла манометричним методом. Проведено зброджування вибраними дріжджами модельного сусла - розчину иукрози. Визначення кількості виділеного вуглекислого газу на різних етапах бродіння здійснювали за динамікою наростання тиску, який за допомогою аналітичних рівнянь перераховували в об'єм. Розрахований об'єм виділеного вуглекислого газу в системі порівнювали з об'ємом, який заміряли при його відведенні в атмосферу (від заданого значення тиску до 0) стандартним методом «методом мокрого газгольдера». Розділивши значення тиску чи об'єму вуглекислого газу на час, знаходили швидкість накопичення тиску чи об'єму за одиниию часу - бродильну активність дріжджів. На підставі проведених експериментів доведена можливість використання манометричного методу та аналітичних розрахунків для експрес-методу знаходження виділеного вуглекислого газу у зброджуваному суслі при визначенні бродильної активності дріжджів. Результати, одержані манометричним методом, в межах точності досліду узгоджуються із результатами, одержаними стандартним методом («методом мокрого газгольдера»). При знаходженні виділеного об 'єму вуглекислого газу манометричним методом середні похибки головним чином залежать від точності вимірювань тиску і становлять 1,5\%об.

Ключові слова: бродильна активність дріжджів, вуглекислий газ, манометричний метод. 
Постановка проблеми. Дріжджі $є$ основною сировиною в технології бродильних, хлібопекарних і кондитерських виробництв. Головним показником якості дріжджів $€$ їх бродильна активність.

Бродильна активність дріжджів - це спроможність одиниці маси дріжджів за одиницю часу при заданій температурі і pH зброджувати певну масу цукрів до етилового спирту й вуглекислого газу. Різні цукри зброджуються 3 різною швидкістю. Перш за все зброджуються глюкоза і фруктоза. Повільніше зброджуються мальтоза і цукроза, які попередньо за допомогою ферментів дріжджів гідролізуються до простих цукрів. Залежно від цукру, який у лабораторних умовах використовується в зброджуваному суслі, розрізняють зимазну і мальтазну активність дріжджів.

Зимазна активність дріжджів - це швидкість зброджування дріжджами глюкози чи цукрози.

Мальтазна активність дріжджів — це швидкість зброджування дріжджами мальтози.

Бродильну активність дріжджів визначають такими методами:

- за зменшенням маси проби після бродіння за рахунок втрати вуглекислого газу, що є критерієм сили бродіння;

- за об'ємом виділеного вуглекислого газу;

- за кількістю накопиченого етилового спирту;

- за кількістю незбродженого екстракту (цукру), що залишився.

Широко розповсюджене визначення бродильної активності дріжджів за об'єму виділеного вуглекислого газу здійснюється на різноманітних конструкціях лабораторних установок - зимографів. Але всі вони мають головний недолік - визначення відбувається на стадії пристосування дріжджів (лаг-фаза) до середовища бродіння, а результати мають більше порівняльний характер, ніж відображають реальну картину динаміки бродіння.

Визначення бродильної активності дріжджів за замірами показників накопиченого етилового спирту і незбродженого дійсного екстракту при зброджуванні заданого сусла в лабораторних умовах дають більш-менш повну уяву про динаміку бродіння. Знаходження вищенаведених показників стандартними методами для відстежування динаміки бродіння громіздке, трудоємке і мало придатне навіть у лабораторних умовах. Використання аналітичного та рефрактометричного методів визначення етилового спирту і дійсного екстракту для оперативного відстежування динаміки бродіння в лабораторних умовах усуває цю проблему [1].

Зброджування квасного чи пивного сусла на виробництві здійснюється під надлишковим тиском не більше 0,7 бар. Також кожен метр висоти шару сусла створює на дріжджову клітину гідростатичний тиск близько 0,1 бар. То ж при надлишковому тиску вуглекислого газу в апараті 0,7 бар і висоті шару сусла в апараті 10 м, дріжджова клітина, що знаходиться на дні апарата, піддаватиметься тиску в 1,7 бар. Тому всі вище наведені лабораторні методи визначення бродильної активності дріжджів, не можуть дати повної і точної уяви про інтенсивність процесу бродіння в промислових умовах, внаслідок значного впливу надлишкового тиску на життєдіяльність дріжджових клітин і, відповідно, на значення їх бродильної активності. 
Для визначення бродильної активності дріжджів, з урахуванням дії надлишкового тиску, запропоновано використовувати знаходження виділеного вуглекислого газу манометричним методом при наростанні тиску від 0 до 1,0 бар.

Аналіз останніх досліджень і публікацій. Для всіх продуктів бродіння, таких як модельні суміші (для визначення бродильної активності дріжджів за динамікою бродіння), квас, пиво, вино, чи спиртова бражка, попередником $\epsilon$ сусло. Сусло складається 3 води і розчинних сухих речовин, які називаються екстрактом. Менша частина екстракту дріжджами не зброджується, залишаючись у суслі в незмінному вигляді. Більша частина екстракту, що являє собою прості цукри (глюкозу, фруктозу), дисахариди (мальтозу, цукрозу, або трисахарид мальтотріозу), зброджується дріжджами до етилового спирту i вуглекислого газу. Виділення вуглекислого газу із сусла відбувається еквівалентно накопиченому в суслі етиловому спирту і збродженим цукрам.

Відомий газометричний спосіб визначення бродильної активності хлібопекарських дріжджів [2].

Спосіб включає такі операції: підготовку насиченого розчину хлориду натрію, підфарбованого метиленовим синім, який заливають в манометричну кришку з вимірювальною трубкою приладу. До дріжджової суспензії, вміщеної в стаканчику приладу, додають $10 \mathrm{~cm}^{3} 10 \%$ розчину цукру (глюкози або мальтози), потім стаканчик закривають манометричною кришкою і ставлять в термостат при температурі $35^{\circ} \mathrm{C}$. Далі починають відлік часу і спостерігають за приладом, поки не виділиться $10 \mathrm{~cm}^{3}$ вуглекислого газу і розчин у вимірювальній трубці не підніметься на відповідну висоту. Запропонований спосіб здійснюється за допомогою газоміру Єлецького.

Недоліками способу є необхідність приготування розчину хлориду натрію, підфарбованого метиленовим синім і неточність результату.

Відомий також спосіб визначення мальтазної активності пресованих дріжджів (метод ВНДІХПа) [3].

Спосіб також передбачає приготування насиченого розчину хлориду натрію, яким заповнюють чашковий манометр з градуйованою трубкою. Потім в чашечці приладу відважують дріжджі і розводять їх $10 \mathrm{~cm}^{3}$ водопровідної води, підігрітої до $30^{\circ} \mathrm{C}$, сюди ж додають $10 \mathrm{~cm}^{3} 10 \%$ розчину мальтози, підігрітого до $35^{\circ} \mathrm{C}$. Чашечку приладу закривають кришкою з манометром і ставлять в термостат з температурою $30^{\circ} \mathrm{C}$.

Мальтазну активність відзначають за часом, коли рідина в градуйованій трубці підніметься на $10 \mathrm{~cm}^{3}$ понад початкову позначку. Недоліками способу $\epsilon$ необхідність приготування розчину хлориду натрію і наявність приладу виробничого виготовлення, а також неточність отриманих результатів.

Відомий спосіб визначення бродильной активності пивних дріжджів, розроблений в Чехії Калером [4]. Спосіб полягає в тому, що готують $20 \%$ розчин хлориду натрію, підкислений ортофосфорною кислотою до $\mathrm{pH} 1$ i заповнюють бюретку. У колбу поміщають 0,7 г пивних дріжджів і $30 \mathrm{~cm}^{3}$ розчину мальтози, приготованого на $0,2 \%$ розчині $\mathrm{KH}_{2} \mathrm{PO}_{4}$. Бродіння ведуть протягом 3 годин при температурі $20^{\circ} \mathrm{C}$, відзначаючи кожну годину рівень рідини в бюретці.

Недоліками способу є необхідність приготування допоміжного розчину і неточність результатів. 
Для підвищення точності вимірювань, дослідження різних газоутворюючих середовищ існує пристрій, що складається з бродильної посудини (колби) будь-якого об'єму, газовідвідної трубки, краника з рухливою частиною, гумової пробки і чутливого манометра [5].

Перед початком роботи вимірюють об'єм колби до нижнього краю ретельно притертої гумової пробки та об'єм газовідвідної трубки, що проходить через пробку. Отриману величину приймають за «постійну».

У колбу поміщають реагуючу суміш, що складається із суспензії дріжджів (квасних, пивних, винних, спиртових, хлібопекарних тощо) та розчину цукру (мальтози або глюкози), герметично закривають пробкою і з'єднують 3 манометром через газовідвідну трубку з краном. Для вирівнювання тиску в колбі 3 атмосферним тиском витягують рухому частину крану і відразу ж повертають на місце, обережно притираючи і суміщуючи отвори.

Підготовлений таким чином прилад розміщують у термостаті при температурі $20-35^{\circ} \mathrm{C}$ залежно від мети дослідження. Далі спостерігають і фіксують час, за який стрілка манометра досягає позначки, що відповідає необхідній кількості виділеного вуглекислого газу.

Величину тиску, що створюється вуглекислим газом у визначеному раніше об’ємі колби, визначають за формулою, виведеною з рівняння Клапейрона-Мендєлєєва:

$$
P_{x}=\frac{m \cdot R \cdot T_{x}}{V_{x} \cdot M},
$$

де $m$ - маса вуглекислого газу (для об'єму, що виділяється у приладі), г; $R$ - універсальна газова постійна, $62360 \frac{\mathrm{Mм} \mathrm{Hg} \cdot \mathrm{cm}^{3}}{\mathrm{моль} \cdot K} ; T_{x}$ - температура інкубації, $K ; V_{x}$ - вільний об'єм газового простору приладу, см³ $; M-$ молекулярна маса вуглекислого газу, 44,010 г.

Спосіб дає змогу точно фіксувати необхідну кількість виділеного вуглекислого газу за допомогою пристрою, який можна зібрати в будь-якій лабораторії. Підвищення точності вимірювань пов'язане, з одного боку, з технічними характеристиками манометра, оскільки похибка 4 мм Нg для мембранного манометра більш пріоритетна, ніж $1 \mathrm{~cm}^{3}$ вимірювальної трубки, що відповідає приблизно 6 мм Нg. Градуювання у всіх попередніх запропонованих методах відбувається 3 точністю до $1 \mathrm{~cm}^{3}$. 3 іншого боку, розрахунок маси $10 \mathrm{~cm}^{3}$ вуглекислого газу за допомогою рівняння Клапейрона-Мендєлєєва виключає вплив умов експерименту (температура і атмосферний тиск) на його результат.

Приклад 1. У колбу вносили 0,5 г пресованих хлібопекарних дріжджів для визначення бродильної активності, заливали $10 \mathrm{~cm}^{3}$ водопровідної води температурою $35^{\circ} \mathrm{C}$. Потім додавали $10 \mathrm{~cm}^{3} 10 \%$ розчину глюкози (мальтози) і закривали колбу гумовою пробкою 3 газовідвідною трубкою, з'єднаною 3 манометром. Прилад поміщали в термостат при $35^{\circ} \mathrm{C}$ та реєстрували час, протягом якого стрілка манометра досягає необхідної позначки, що відповідає $10 \mathrm{~cm}^{3}$ виділеного вуглекислого газу. 
Величину тиску визначали з рівняння Клапейрона-Мендєлєєва:

$$
P_{x}=\frac{0,016 \cdot 62360 \cdot 308}{104 \cdot 44,010}=67,15 \mathrm{Mm} \mathrm{Hg},
$$

де $m=0,016$ г; $T_{x}=308 \mathrm{~K} ; V_{x}=104 \mathrm{~cm}^{3}$.

Значення $V_{x}$ вираховували відніманням від загального об'єму колби і газовідвідної трубки (124,5 cм³) об'єму дріжджової суспензії $\left(20,5 \mathrm{~cm}^{3}\right)$.

Тож час, затрачений на виділення $10 \mathrm{~cm}^{3} \mathrm{CO}_{2}$, або зимазна (мальтазна) активність, склав 45 хвилин (70 хвилин), що свідчить про хорошу якість дріжджів.

Для визначення бродильної активності хлібопекарних дріжджів дотримуються умови, прийнятої в галузі: кількість пресованих дріжджів - 0,5 г; кількість субстрату - $10 \mathrm{~cm}^{3} 10 \%$ розчину цукру (глюкоза, мальтоза); кількість водопровідної води - $10 \mathrm{~cm}^{3}$; температура інкубації $35^{\circ} \mathrm{C}(308 \mathrm{~K})$; необхідна кількість виділеного вуглекислого газу в приладі $-10 \mathrm{~cm}^{3}$. Цим умовам відповідає прийнята в галузі градація бродильної активності:

- хороша зимазна (мальтазна) - $30-40$ хв (50-90 хв);

- задовільна зимазна (мальтазна) - 40-70 хв (90-100 хв);

- незадовільна зимазна (мальтазна) - більше 70 хв (більше 100 хв).

Приклад 2. Заміряний об’єм системи склав $331 \mathrm{~cm}^{3}$. У колбу вносили 0,7 г відпресованих на лійці пивних дріжджів 129 раси для визначення бродильної активності, $30 \mathrm{~cm}^{3} 10 \%$ розчину мальтози, приготовлені на $0,2 \%$ розчині $\mathrm{KH}_{2} \mathrm{PO}_{4}$ і розбавлені до одержання однородної суспензії. Колбу ретельно закривали і через газовідвідну трубку з'єднували з манометром. Прилад поміщали в термостат при $20^{\circ} \mathrm{C}$ та реєстрували час, протягом якого стрілка манометра досягає розрахункового значення тиску, що відповідає $25 \mathrm{~cm}^{3}$ виділеного вуглекислого газу. Величина тиску склала 65 мм Нg.

Отже, бродильная активність 129 раси дріжджів склала 172 хвилини, що свідчить про хорошу бродильну активність дріжджів.

Для визначення бродильної активності пивних дріжджів дотримуються умови, прийнятої в галузі: кількість відпресованих на лійці дріжджів - 0,7 г; кількість субстрату - $30 \mathrm{~cm}^{3} 10 \%$ мальтози на $0,2 \%$ розчині $\mathrm{KH}_{2} \mathrm{PO}_{4}$, температура інкубації $-20^{\circ} \mathrm{C}(293 \mathrm{~K})$, бродіння ведуть протягом 3 годин. Цим умовам відповідає прийнята в галузі градація бродильної активності: за 3 години хороші дріжджі виділяють $25-28 \mathrm{~cm}^{3} \mathrm{CO}_{2}$.

Використання цього способу дає змогу зменшити витрати реактивів, мати достатньо точну інформацією про якість дріжджів, що використовуються, а також визначати газоутворюючу здатність борошна та напівфабрикатів (закваски, опари тощо), розширюючи таким чином діапазон технологічних показників, що визначаються на цьому приладі.

Усі наведені вище методи знаходження величини бродильної активності дріжджів грунтуються на тому принципі, що визначення відбувається у відповідним чином підготовлених зразках дріжджів (як товарному продукті, що має певні якісні показники) на модельних зразках сусла (глюкози чи мальтози) на стадії пристосування дріжджів (лаг-фаза) до зброджування сусла. 
Дуже часто в лабораторній практиці $є$ необхідність визначення бродильної активності дріжджів в умовах, близьких до виробничих. Також буває необхідно оперативно заміряти значення цієї величини стосовно контролю, що дає можливість усунути вплив різних факторів, які неможливо врахувати. При цьому на величину бродильної активності дріжджів (у динаміці життєдіяльності дріжджів, після внесення в сусло визначеної кількості дріжджів), будуть мати вплив:

- кількість дріжджових клітин в одиниці об'єму;

- стан дріжджових клітин;

- стадія розвитку дріжджових клітин;

- склад сусла;

- температура сусла;

- тиск, при якому проходить зброджування сусла.

Мета дослідження: визначення бродильної активності дріжджів при зброджуванні модельного сусла в умовах близьких до виробничих за кількістю виділеного вуглекислого газу. Цей параметр вимірюється з високою точністю манометричним методом і $є$ короткочасним, що дає можливість проводити експрес-аналізи.

Матеріали і методи. Для досліджень використовували цукор білий за ДСТУ 4623, воду дистильовану за ГОСТ 6709, дріжджі хлібопекарські пресовані за ДСТУ 4812 чи дріжджі сухі інстантні (високоактивні).

Для визначення бродильної активності дріжджів за кількістю виділеного вуглекислого газу манометричним методом, при зброджуванні ними модельного сусла в умовах близьких до виробничих, пропонується пристрій, що складається 3 двох бродильних циліндрів (посудин), з герметичними кришками, газовідвідними трубками, кранами (сполучення з атмосферою чи манометрами) і подвійним манометром.

Перед початком роботи вимірювали об'єм циліндрів 3 газовідвідними трубками. Отриману величину приймали за «постійну». В конкретному випадку «постійна» становить $490 \mathrm{~cm}^{3}$.

Для експериментальної оцінки методу готували сусло $310 \%$ мас. концентрацією цукрози. До сусла додавали дріжджі в кількості 1,0\% мас. за сухими речовинами (СР). Сусло зброджували періодичним способом при температурі $30^{\circ} \mathrm{C}$. Об'єм зброджуваного сусла може коливатися від $100 \mathrm{~cm}^{3}$ до $400 \mathrm{~cm}^{3}$ Визначення кількості виділеного вуглекислого газу на різних етапах бродіння здійснювали за динамікою наростання тиску в контролі i досліді, який за допомогою аналітичних рівнянь перераховували в об'єм. Розрахований об'єм виділеного вуглекислого газу в системі порівнювали 3 об'ємом, який заміряли при його відведенні в атмосферу (від заданого значення тиску до 0) за допомогою «методу мокрого газгольдера».

Вуглекислий газ за допомогою трубки спрямовували в перевернутий градуйований циліндр, заповнений підфарбованим метиленовим синім, насиченим розчином хлориду натрію, при цьому край циліндра знаходився під шаром аналогічної рідини в посудині.

Для врівноваження тиску вуглекислого газу всередині циліндра 3 атмосферним переміщали циліндр до однакових рівнів рідини всередині циліндра і ззовні його (в посудині). Після цього проводили відлік об'єму вуглекислого газу. 
Щоб уникнути впливу об’єму вуглекислого газу, що виділяється за час проведення вимірювань, для цього етапу бродіння заміряли час набору тиску від 0 до заданого значення. Відведення накопиченого вуглекислого газу 3 приладу в циліндр розпочинали раніше, а відлік значення виділеного об'єму вуглекислого газу здійснювали точно в попередньо визначений час набору заданого значення тиску.

Розділивши значення тиску чи об’єму вуглекислого газу на час, знаходили швидкість накопичення тиску чи об'єму за одиницю часу - бродильну активність дріжджів.

Результати і обговорення. Об'єм циліндрів з газовідвідними трубками («постійна») становить $490 \mathrm{~cm}^{3}$. Об'єм зброджуваного сусла брали $200 \mathrm{~cm}^{3}$, а заданий надлишковий тиск -1 кгс/см² $=98066,5$ Па.

Перерахунок тиску в об'єм при нормальних умовах (температура $0^{\circ} \mathrm{C}$, тиск 101325 Па), який створює виділений вуглекислий газ, визначали за формулою:

$$
V_{0}=\frac{273,15 \cdot\left(490-v_{t}\right) \cdot\left(P_{t}+B-p_{t}\right)}{101325 \cdot(273,15+t)}+\frac{\alpha \cdot v_{t}\left(P_{t}+B-101325\right)}{101325},
$$

де $V_{0}$ - об'єм виділеного вуглекислого газу, приведений до нормальних умов, $\mathrm{cm}^{3} ; v_{t}-$ об'єм зброджуваного сусла при заданій температурі, $\mathrm{cm}^{3}\left(v_{t}=200 \mathrm{~cm}^{3}\right)$; $P_{t}$ - надлишковий тиск в бродильних циліндрах при заданій температурі, Па $\left(P_{t}=98066,5\right.$ Па); $B$ - барометричний тиск під час проведення досліду, Па ( $B=$ 100000 Па); $p_{t}$ - тиск насиченої водяної пари при заданій температурі, Па $\left(p_{t}=4242\right.$ Па); $t$ - задана температура, ${ }^{\circ} \mathrm{C}\left(t=30^{\circ} \mathrm{C}\right) ; \propto-$ коефіцієнт абсорбції вуглекислого газу в воді при заданій температурі, $(\propto=0,665)$.

Впливом вмісту цукру і етилового спирту в зброджуваному суслі на коефіцієнт абсорбції вуглекислого газу $\alpha$ нехтували.

$$
\begin{aligned}
& V_{0}=\frac{273,15 \cdot(490-200) \cdot(98066,5+100000-4242)}{101325 \cdot(273,15+30)}+ \\
& +\frac{0,665 \cdot 200 \cdot(98066,5+100000-101325)}{101325}=626,8 \mathrm{~cm}^{3} .
\end{aligned}
$$

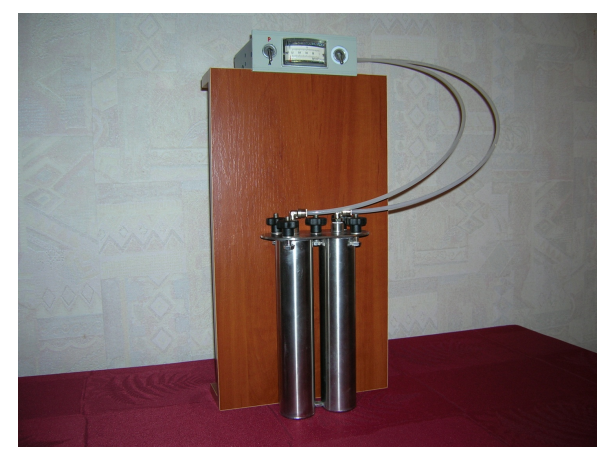

Рис. Лабораторна установка для визначення бродильної активності дріжджів манометричним методом 
У подальшому, за допомогою «методу мокрого газгольдера», заміряли об'єм вуглекислого газу при його відведенні в атмосферу (від заданого значення тиску до 0) і порівнювали з розрахунками. Дані експерименту в паралельних дослідах для двох різних бродильних циліндрів («Дослід» і «Контроль») наведені в таблиці. Лабораторна установка приведена на рисунку.

При знаходженні виділеного об'єму вуглекислого газу манометричним методом середні похибки головним чином залежать від точності вимірювань тиску і становлять в даному випадку 1,5\%об.

Таблиия. Залежність значень розрахованих і заміряних об'смів виділеного вуглекислого газу від тиску, накопиченого в лабораторній установці

\begin{tabular}{|c|c|c|c|c|}
\hline \multirow{2}{*}{$\begin{array}{c}\text { Назва } \\
\text { бродильного } \\
\text { циліндра }\end{array}$} & \multirow{2}{*}{$\begin{array}{l}\text { Тиск у } \\
\text { приладі, } \\
\text { кгс/см }\end{array}$} & \multicolumn{2}{|c|}{ Визначення вуглекислого газу } & \multirow{2}{*}{$\begin{array}{l}\text { Приведена } \\
\text { похибка, \% }\end{array}$} \\
\hline & & $\begin{array}{c}\text { аналітичним методом } \\
\text { за тиском, } \mathrm{cm}^{3}\end{array}$ & $\begin{array}{l}\text { методом «мокрого } \\
\text { газгольдера», } \text { см }^{3}\end{array}$ & \\
\hline \multirow{5}{*}{ «Дослід» } & 0,2 & 125 & 120 & 0,80 \\
\hline & 0,4 & 251 & 247 & 0,64 \\
\hline & 0,6 & 376 & 370 & 0,96 \\
\hline & 0,8 & 501 & 497 & 0,64 \\
\hline & 1,0 & 627 & 620 & 1,12 \\
\hline \multirow{5}{*}{ «Контроль» } & 0,2 & 125 & 122 & 0,48 \\
\hline & 0,4 & 251 & 245 & 0,96 \\
\hline & 0,6 & 376 & 373 & 0,48 \\
\hline & 0,8 & 501 & 495 & 0,96 \\
\hline & 1,0 & 627 & 622 & 0,80 \\
\hline
\end{tabular}

\section{Висновки}

На підставі проведених експериментів доведена можливість використання манометричного методу та аналітичних розрахунків для експрес-методу знаходження виділеного вуглекислого газу у зброджуваному суслі при визначенні бродильної активності дріжджів. Результати, одержані манометричним методом, в межах точності досліду узгоджуються з результатами, одержаними стандартним методом - «методом мокрого газгольдера». Короткочасність, доступна апаратура і нескладна методика вимірювань дають можливість широко використовувати метод у лабораторній практиці.

\section{Лiтература}

1. Рідкоус В.В. Визначення бродильної активності дріжджів по спирту і екстракту рефрактометричним методом. Наукові праці Національного університету харчових технологій. 2018. Т. 24, № 4. С. 178-184.

2. Справочник по производству хлебопекарных дрожжей / Под ред. С.С. Новаковской, Ю.И. Шишацкого. Изд. 2-е, перераб. и доп. Москва : Пищевая промышленность, 1980. C. $217-218$.

3. Технология и технохимический контроль хлебопекарного производства. / Под ред. Л.Ф. Зверевой, 3.С. Немцовой, Н.П. Волковой. Изд. 3-е. Москва: Легкая и пищевая промышленность, 1983. С. 364.

4. Микробиология в пищевой промышленности / Под ред. А.Ю. Жвирблянской, О.А. Бакушинской. Москва: Пищевая пром-сть, 1975. С. 364-365.

5. Способ оценки ферментативной активности дрожжей : пат. Российской Федерации № 2229126 ; заявл. 07.05.2001 ; опубл. 20.05.2004. URL: http://www.freepatent.ru/patents/2229126 (дата звернення: 14.10.2018). 